\title{
Quality of life in chronic venous disease women
}

\section{Qualidade de vida em mulheres com doença venosa crônica}

\section{AUTHOR'S \\ Dalton de Lima-Junior ${ }^{1}$ (D) \\ Ozeas Lins-Filho ${ }^{1}$ (D) \\ Jessica da Silva ${ }^{1}$ (D) \\ Giselly Leite ${ }^{1}$ (D) \\ Luana Gusmão ${ }^{1}$ (iD) \\ Daniela Karina da Silva Ferreira $^{1}$ (D) \\ 1 Universidade Federal de Pernambuco, \\ Departamento de Educação Física, Recife, \\ Pernambuco, Brasil.}

\section{CORRESPONDING}

\section{Daniela Karina da Silva Ferreira}

daniela.karina@ufpe.br

Federal University of Pernambuco. Physical

Education Department. Av. Prof. Moraes

Rego, 1235, Cidade Universitária, Recife,

Pernambuco, Brasil. CEP: 50670-901.

\section{DOI}

10.12820/rbafs.23e0036

\section{(ब) $\Theta \Theta$}

Copyright: This is an open-access article distributed under the terms of the Creative Commons Attribution License ${ }^{\circledR}$, which permits unrestricted use, distribution, and reproduction in any medium, provided that the original author and source are credited.

\begin{abstract}
The aim of the study was to verify the relationship between physical function and quality of life in women with chronic venous disease. Physical function was evaluated by the tests: chair stand test (lower limbs strength), arm curl (upper limbs strength), 6-minute walk (aerobic fitness), back scratch (upper limbs flexibility), sit and reach (lower limbs flexibility), and time up-and-go (agility). Quality of life was assessed by The World Health Organization Quality of Life-BREF (WHOQOL-BREF) questionnaire, which is composed by physical, psychologic, social, environmental, and global domains. For statistical analysis, the Pearson correlation coefficient was used with an alpha of $5 \%$. Patients evaluated were 32 (61.27 \pm 7.78 years). A significant correlation was observed between the physical domain of quality of life with the chair stand test $(r=0.46 ; p=0.001)$, arm curl $(r=0.39, p=$ $0.002)$, and 6 -minute walk test $(r=0.45 ; p=0.001)$. Also, chair stand test presented low correlation with global quality of life $(r=0.36, p=0.004)$. The physical domain of quality of life measured by the WHOQOL-BREF questionnaire is related to lower and upper limbs strength and physical fitness in women with chronic venous disease but presented weak correlation with the global domain of quality of life. Thus, in women with CVD, the muscular strength of lower and upper limbs, and physical fitness is correlated with the physical domain of quality of life.
\end{abstract}

Keywords: Chronic venous insufficiency; Health; Muscular strength; Vascular disease.

RESUMO

O objetivo do estudo foi verificar a relaçâo entre capacidade física e qualidade de vida em mulheres com doença venosa crônica. A capacidade física foi avaliada pelos testes: sentar e levantar (força de membros inferiores), flexão de braço (força de membros superiores), teste de caminhada de seis minutos (resistência aeróbia), alcançar as costas (flexibilidade de membros superiores), sentar e alcançar (flexibilidade de membros inferiores) e levantar ir-e-vir (agilidade). Qualidade de vida foi avaliada pelo questionário da Organização Mundial de Saúde WHOQOL-BREF composto pelos dominios físico, psicológico, social, ambiental e global. Correlação de Pearson foi usada para verificar a relação entre as variáveis. $O$ valor de alpha foi estabelecido em 5\%. Foram avaliados 32 pacientes (61.27 \pm 7.78 anos). Correlaçôes significativas foram observadas entre os dominios físico de qualidade de vida com o teste de sentar e levantar $(r=0.46 ; p=0.001)$, flexão de braço $(r=0.39 ; p=0.002)$, e teste de seis minutos de caminhada $(r=0.45 ; p=0.01)$. Além disso, 0 teste de sentar e levantar apresentou fraca correlação com o dominio qualidade de vida global $(r=0.36 ; p=$ 0.004). Conclui-se que a resistência aeróbia e força muscular de membros superiores e inferiores tem relação com o dominio físico de qualidade de vida em mulheres com doença venosa crônica.

Palavras-chave: Doença venosa crônica; Saúde; Força muscular; Doença vascular.

\section{Introduction}

Chronic venous disease (CVD) is defined as visual and functional manifestation of abnormalities in peripheral venous system that either present or not symptoms that alter superficial and deep veins ${ }^{1}$. Its prevalence is estimated in $60 \%$ of the adult population in developed countries ${ }^{2}$. Although, the prevalence might be even greater because the first stages of the disease are asymptomatic $^{2,3}$. Moreover, despite CVD affects both men and women, due to pregnancy and hormonal function, women are more susceptible to the disease ${ }^{3}$. In the last two decades, several epidemiological studies from different populations have shown that patients with CVD are majority women, its prevalence is up to $46.0 \%$, whereas in men the prevalence reaches no more than $29.0 \%{ }^{4-7}$. Also, in the Framingham Study ${ }^{8}$ the incidence of CVD per year is 2,6\% in women, whereas in men is only $1,9 \%$. Following those facts, women seem to be more susceptible to CVD than men.

As several chronic diseases, CVD is progressive and present diverse stages. CVD is classified by clinical, etiology, anatomy, and physiology criteria (CEAP) that ranges from $\mathrm{C} 0$ to $\mathrm{C} 6$. $\mathrm{C} 0$, non-visible and non-palpable signs of venous disease; $\mathrm{C} 1$, telangiectasia or reticular veins; $\mathrm{C} 2$, varicose veins; $\mathrm{C} 3$, edema; $\mathrm{C} 4$, changes of skin and subcutaneous tissue (4a pigmentation or 
eczema; 4b lipodermatosclesrosis or atrophie blanche); C5, healed venous ulcer; and C6, active venous ulcer ${ }^{1}$.

The etiology of CVD remains elusive, although, it is known reflux plays a main role in the disease, causing venous hypertension and consequently damages in the venous system ${ }^{3}$. Furthermore, dysfunction in the venous system of lower limbs might be compensated by calf muscle pump function, which is responsible for about $65.0 \%$ of venous return ${ }^{9}$. Nevertheless, patients with CVD seem to have impairment in calf muscle ${ }^{10}$.

In fact, literature reveals that a reduction in functional capacity of the calf muscle is associated with symptoms as tiredness, leg pain, edema, and numbness that influence, negatively, physical function ${ }^{11,12}$ and quality of life ${ }^{13}$. In previous studies, patients with CVD when compared to the healthy ones presented lower gait velocity $(4.5 \pm 1.26 \text { vs } 5.2 \pm 0.5 \mathrm{~km} / \mathrm{h})^{12}$, lesser score in heel-rise test $(14.6 \pm 7.3$ vs $23.5 \pm 6.5$ heel-rises) ${ }^{12}$, and reduced ankle range of motion ${ }^{11}$.

Additionally, patients with symptoms face lower scores of quality of life than the healthy ones. Thereby, it indicates symptoms of the disease influence the perception of quality of life of the patients ${ }^{14}$. Following those facts, despite individuals with CVD reported low level of physical activity and decreased scores of quality of life due to deleterious effect of the disease, it is not elucidated in the literature the relationship between physical activity and quality of life in that population. Therefore, lack of treatment and a fair control of the disease might decrease even more those characteristics of the patients. Thus, the aim of the study is to analyze the relationship between physical function and quality of life in women with CVD.

\section{Methods}

The participants were women with CVD diagnosed by a phlebologist. The recruitment was carried out through local media advertisings as well as flyers distributed in hospitals and surrounding areas of the Federal University of Pernambuco. As inclusion criteria, the patients had to be able to perform physical activity, assured by a physician, and not being engaged in any physical activity for the last six months. Patients who presented any physical or cardiovascular problem during the tests were excluded. All the patients were instructed about the procedures and the ones who agreed with the terms have signed and given their consent for participating into the study according to declaration of Helsinki. The Human Research Ethics Committee approved the stu- dy protocol (CAAE: 29244014.4.0000.5208).

This is a descriptive correlational study. In the first visit, measures of weight and height were obtained and posteriorly body mass index (BMI) was calculated in $\mathrm{kg} / \mathrm{m}^{2}$. In the second visit, quality of life was assessed by World Health Organization Quality of Life shortform (WHOQOL-BREF) ${ }^{15}$ and familiarization of physical function tests. In the third visit, a minimum of two days was required from the second visit, the patients performed the Senior Fitness Test for physical function assessment ${ }^{16}$.

Height was measured by a stadiometer (Filizola, São Paulo, Brazil) with $0.5 \mathrm{~cm}$ precision. Weight was obtained by a scale (Filizola, São Paulo, Brazil) with $0.1 \mathrm{~kg}$ precision. Following previous measurements, BMI was calculated.

Quality of life was assessed by the WHOQOL-BREF. Data were collected by interviewing the patients in a private room and all assessments were performed by only one interviewer. The questionnaire contains 26 questions, two regarding global perception of quality of life and health satisfaction, the other questions are divided in four domains: physical, psychological, social and environment. All questions are depicted in Likert style. Results are interpreted as scales from 0 to 100 , each domain is evaluated in a positive scale, the higher the score the higher quality of life. The questionnaire was chosen due recommendation of World Health Organization due to good internal consistency and reliability in several populations ${ }^{17}$.

Physical function was measured by the Senior Fitness Test ${ }^{16}$. The tests consist of six tests that evaluate upper limbs strength (arm curl), lower limbs strength (chair stand), aerobic fitness (6-minute walk), upper limb flexibility (back scratch), lower limb flexibility (sit-and-reach), agility and dynamic balance (up and go). The respective tests are validated ${ }^{16}$. All the participants were familiarized with the tests and each test was performed twice. The best score was computed.

According to Bonnet \& Wright ${ }^{18}$, the minimum sample size to perform the Person Correlation is 25 . Therefore, to avoid drop-out effect in the analysis, 32 participants were recruited in the study. Data were depicted in mean and standard deviation. Shapiro-Wilk test was performed to verify data distribution. Pearson's Correlation test was used to analyze correlation between physical function and quality of life. All data was analyzed by the software SPSS v. 23 (SPSS Inc., Chicago, IL, USA). Alpha value adopted was 5.0\%. 


\section{Results}

Participants were 32 women with CVD $(61.27 \pm 7.78$ years old; $70.25 \pm 11.70 \mathrm{~kg}$ and $1.52 \pm 0.62 \mathrm{~m})$. Sociodemographic characteristics revealed $60.0 \%$ are above 60 years old, $44.2 \%$ are married, and $56.0 \%$ reported eight or more years of education (Table 1 ). In Table 2 were presented mean and standard deviation of physical function variables and quality of life domains of the patients.

Table 1 - Characteristics of the chronic venous disease patients that participated in the study. Recife, $2017(\mathrm{n}=32)$.

\begin{tabular}{|c|c|c|}
\hline Variables & $\mathrm{n}$ & $\%$ \\
\hline \multicolumn{3}{|c|}{ Age (years) $(\mathrm{n}=32)$} \\
\hline $30-39$ & 2 & 5.0 \\
\hline $40-49$ & 3 & 9.0 \\
\hline $50-59$ & 8 & 26.0 \\
\hline 60 or more & 19 & 60.0 \\
\hline \multicolumn{3}{|c|}{ Body mass index $\left(\mathrm{m} / \mathrm{kg}^{2}\right)(\mathrm{n}=32)$} \\
\hline $18.5-24.9$ & 5 & 16.0 \\
\hline $25-29.9$ & 15 & 47.0 \\
\hline $30-34.9$ & 4 & 12.0 \\
\hline 35 or more & 8 & 25.0 \\
\hline \multicolumn{3}{|c|}{ Medication taken for varicose veins $(\mathrm{n}=32)$} \\
\hline Yes & 7 & 22.0 \\
\hline No & 25 & 78.0 \\
\hline \multicolumn{3}{|c|}{ Smoking status $(\mathrm{n}=32)$} \\
\hline Yes & 2 & 6.0 \\
\hline No & 30 & 94.0 \\
\hline \multicolumn{3}{|c|}{ Menopause $(\mathrm{n}=32)$} \\
\hline Yes & 28 & 87.0 \\
\hline No & 4 & 13.0 \\
\hline \multicolumn{3}{|c|}{ Education (years) $(\mathrm{n}=32)$} \\
\hline $0-3$ & 5 & 16.0 \\
\hline $4-7$ & 9 & 28.0 \\
\hline 8 or more & 18 & 56.0 \\
\hline
\end{tabular}

In Table 3 is illustrated the correlation coefficients between the variables in women with CVD. Physical domain presented significant correlation with lower limbs strength $(r=0.46 ; p=0.001)$, upper limbs strength $(\mathrm{r}=0.39 ; \mathrm{p}=0,002)$, and physical fitness $(\mathrm{r}=$ $0.45 ; \mathrm{p}=0,001)$. Moreover, weak significant correlation for global quality of life and lower limbs strength was found $(r=0.36, p=0.004)$. Psychological, social, and environment domains of quality of life presented no statistically significance for any physical function test.

\section{Discussion}

The results of the study showed that in women with
Table 2 - Physical function and WHOQOL-BREF (quality of life) scores in women with chronic venous disease. Recife, $2017(\mathrm{n}=32)$.

\begin{tabular}{lc}
\hline & Mean \pm SD \\
\hline Physical function & \\
Chair stand (rep) & $10.56 \pm 3.05$ \\
Arm curl (rep)* & $15.02 \pm 4.48$ \\
6-minute walk (m) & $410.27 \pm 85.42$ \\
Back scratch right arm (cm) & $0.51 \pm 3.97$ \\
Back scratch left arm $(\mathrm{cm})$ & $0.74 \pm 4.40$ \\
Sit-and-reach $(\mathrm{cm})^{*}$ & $0.48 \pm 5.13$ \\
Up and go (s) & $7.39 \pm 2.20$ \\
Quality of life & \\
Physical domain & $71.51 \pm 16.59$ \\
Psychological domain & $61.73 \pm 11.63$ \\
Social domain & $68.10 \pm 14.79$ \\
Environment domain & $54.73 \pm 11.31$ \\
Global quality of life & $60.42 \pm 7.90$ \\
\hline
\end{tabular}

* = upper right limb; rep = repetitions; $\mathrm{m}=$ meters; $\mathrm{cm}=$ centimeters; $\mathrm{s}=$ seconds.

Table 3 - Correlation scores between physical function and quality of life in women with chronic venous disease. Recife, $2017(n=32)$.

\begin{tabular}{lcccccc}
\hline Quality of life & $\begin{array}{r}\text { Chair } \\
\text { stand }\end{array}$ & $\begin{array}{c}\text { Arm } \\
\text { curl }\end{array}$ & $\begin{array}{c}\text { 6-min } \\
\text { walk }\end{array}$ & $\begin{array}{c}\text { Back } \\
\text { scratch }\end{array}$ & $\begin{array}{c}\text { Sit-and- } \\
\text { reach }\end{array}$ & $\begin{array}{c}\text { Up and } \\
\text { go }\end{array}$ \\
\hline $\begin{array}{l}\text { Physical domain } \\
\text { Psychological }\end{array}$ & $0.46^{*}$ & $0.39^{*}$ & $0.45^{*}$ & 0.03 & 0.25 & -0.34 \\
$\begin{array}{l}\text { domain } \\
\text { Social domain }\end{array}$ & 0.31 & 0.25 & 0.23 & -0.12 & 0.19 & -0.18 \\
$\begin{array}{l}\text { Environment } \\
\text { domain }\end{array}$ & 0.19 & 0.22 & 0.08 & -0.04 & 0.20 & 0.04 \\
Global & $0.36^{*}$ & 0.29 & 0.24 & -0.10 & 0.23 & -0.06 \\
\hline
\end{tabular}

$* \mathrm{p}<0.005$.

CVD physical domain of quality of life is correlated with lower and upper limb strength, and physical fitness. Furthermore, global quality of life is correlated with lower limbs strength. Nevertheless, flexibility and balance are not correlated with any domain of quality of life.

Patients with CVD present worse scenario of quality of life and lower limb strength when compared to healthy ones ${ }^{11,3}$. Moreover, the worse are the symptoms, the most is the impairment in physical components and quality of life ${ }^{14}$. Thereby, those finds are according with this study, since lower limbs strength showed significant correlation with quality of life $(r=0.46 ; p=$ 0.001), corroborating with the concept that high scores in lower limbs strength indicate better quality of life.

Calf muscle pump dysfunction impacts the venous system $^{3}$ causing mobility impairment, and gait velocity, ankle range of motion, and muscle power reduction ${ }^{11,12}$. Those factors might affect negatively physical health per- 
ception $^{13}$. In fact, patients with CVD have lower scores of muscular function in lower limbs ${ }^{11}$ reducing physical function and consequently daily physical activities ${ }^{5,19}$.That scenario might reflect the lower scores of physical quality of life domain perception as happened in our study.

In fact, progressive loss of physical function affects mainly the physical domain of quality of life ${ }^{13,20}$. Darvall et al. ${ }^{13}$, observed that independently of the stage of the disease patients that reported symptoms as swelling and pain in lower limbs lower scores on physical domain of quality of life than patients without symptoms. Additionally, Palfreyman et al. ${ }^{20}$ reported that CVD symptoms in 16 patients had a negative impact on quality of life. Those results endorse our study.

Although, literature lacks studies about the effect of upper limbs strength on quality of life in women with DVC, this study indicates a relationship between the variables $(r=0.39 ; p=0.002)$. The quality of life in the physical domain of the WHOQOL-BREF questionnaire evaluate quality of life based on capacity of performing daily physical activities, thus physical limitations produced by CVD might result in reduction on daily physical activities ${ }^{21}$ that might explain our results of women with CVD presenting lower levels of physical activity also report low levels of quality of life.

In addition, our results showed that physical fitness is correlated with quality of life on the physical domain $(r=0.45 ; p=0.001)$. In fact, patients with CVD suffer with pain sensation ${ }^{3,19}$, fatigue ${ }^{19}$, reduction in mobility ${ }^{11,12}$ and daily physical activities ${ }^{5}$. Therefore, symptoms are linked to health perception, reducing daily physical activities that affect perception of quality of life and physical fitness ${ }^{22,6}$.

In the present study, correlations were not found among physical function and domains of quality of life. It might be enlightened due functional impairment caused by CVD affects physical domain mainly. Thereby, considering other domains of quality of life reflect information about social traits, support given to the patient, and an environment that achieve their limitations, battery of physical function might not be appropriated for such comparisons. Therefore, is likely that our results yield information primarily regarding physical function.

Although, severity of the disease impacts quality of life and physical function scores ${ }^{23}$, studies about that issue still lack in the literature. Moreover, besides the correlation between several scores of physical function and physical domain of quality of life present moderate correlation $(r=0.39$ to $r=0.46)$, quality of life is affected by several factors and moderate correlation represents worthy information and may lead future intervention to women with the disease.

This study presented some limitations. The questionnaire that measured quality of life in this study (WHOQOL-BREF) is not a specific questionnaire for patients with CVD even though it is largely used in several populations and presents good internal consistency ${ }^{17}$. Our participants were women, and inference for men is not recommended, although women are the most affected by $\mathrm{CVD}^{3}$.

In this study, results identified correlations between essential components affected by CVD as muscular strength, physical fitness and quality of life $^{3}$. In addition, future studies should investigate correlation between other physical components as ankle range of motion and questionnaire specific for the population; also, different designs should be applied to stablish cause-effect. Thus, in women with CVD, muscular strength of lower and upper limbs, and physical fitness measured by The Senior Fitness Test are correlated with the physical domain of the quality of life questionnaire WHOQOL-BREF.

\section{Conflict of interest}

The authors declare no conflict of interest.

\section{Funding}

This study was found by the Coordination for the Improvement of Higher Education Personnel - CAPES.

\section{Author's contributions}

Lima-Junior D and Lins-Filho O, conceived the original idea, developed the theory, collected data, performed the computations and analyses, and wrote the manuscript. Silva J, Leite G and Gusmão L, developed the theory, collected data and wrote the manuscript. Ferreira D, conceived the original idea, developed the theory, supervised the text, provided critical feedback and helped shape the research.

\section{Acknowledgements}

We would like to offer our special thanks to Julie Barros Pessoa and Elizabeth Schilpp for the english language review. Also, we are particularly gratefull to all the volunteers.

\section{References}

1. Kistner RL, Eklof B. Classification and etiology of chronic venous disease. 2017; Handbook of Venous and Lymphatic Disorders: Guidelines of the American Venous Forum: CRC Press, 2017. 
2. Robertson L, Evans C, Fowkes F. Epidemiology of chronic venous disease. Phlebology 2008;2(3):103-11.

3. Wittens C, Davies A, Bækgaard N, Broholm R, Cavezzi A, Chastanet $\mathrm{S}$, et. al. Editor's choice-management of chronic venous disease: Clinical practice guidelines of the European Society for Vascular Surgery (ESVS). Eur J Vasc Endovasc Surg. 2015;49(6):678-37.

4. Carpentier PH, Maricq HR, Biro C, Ponçot-Makinen CO, Franco A. Prevalence, risk factors, and clinical patterns of chronic venous disorders of lower limbs: A population-based study in France. J Vasc Surg. 2004;40(4):650-59.

5. Chiesa R, Marone EM, Limoni C, Volonté M, Schaefer E, Petrini O. Effect of chronic venous insufficiency on activities of daily living and quality of life: correlation of demographic factors with duplex ultrasonography findings. Angiology. 2007;58(4):440-49.

6. Criqui $\mathrm{MH}$, Denenberg JO, Bergan J, Langer RD, Fronek A. Risk factors for chronic venous disease: the San Diego Population Study. J Vasc Surg. 2007;46(2):331-37.

7. Jawien A, Grzela T, Ochwat A. Prevalence of chronic venous insufficiency in men and women in Poland: Multicentre cross-sectional study in 40,095 patients. Phlebology. 2003;18(3):110-22.

8. Brand F, Dannenberg A, Abbott R, Kannel W. The epidemiology of varicose veins: The Framingham Study. Am J Prev Med. 1988;4(2):96-01.

9. Williams KJ, Ayekoloye O, Moore HM, Davies AH. The calf muscle pump revisited. J Vasc Surg. 2014;2(3):329-34.

10. Araki CT, Back TL, Padberg FT, Thompson PN, Jamil Z, Lee BC, et al. The significance of calf muscle pump function in venous ulceration.J Vasc Surg.1994;20(6):872-79.

11. Moura RMF, Alencar Gomes H, Silva SLA, Britto RR, Dias RC. Analysis of the physical and functional parameters of older adults with chronic venous disease. Arch Gerontol Geriatr. 2012;55(3):696-01.

12. van Uden CJ, van der Vleuten CJ, Kooloos JG, Haenen J, Wollersheim H. Gait and calf muscle endurance in patients with chronic venous insufficiency. Clin Rehabil. 2005;19(3):339-44.

13. Darvall K, Bate G, Adam D, Bradbury A. Generic healthrelated quality of life is significantly worse in varicose vein patients with lower limb symptoms independent of CEAP clinical grade. Eur J Vasc Endovasc Surg. 2012;44(3):341-44.
14. Andreozzi G, Cordova R, Scomparin M, Martini R. Quality of life in chronic venous insufficiency: An Italian pilot study of the Triveneto Region. Int Angiol. 2005;24(3):272-77.

15. The WHOQOL Group. Development of the World Health Organization WHOQOL-BREF quality of life assessment. Psychol Med. 1998;28(3):551-58.

16. Rikli RE, Jones CJ. Development and validation of criterionreferenced clinically relevant fitness standards for maintaining physical independence in later years. Gerontologist. 2013;53(2):255-67.

17. Berlim MT, Pavanello DP, Caldieraro MA, Fleck MP. Reliability and validity of the WHOQOL BREF in a sample of Brazilian outpatients with major depression. Qual Life Res. 2005;14(2):561-64.

18. Bonett DG, Wright TA. Sample size requirements for estimating pearson, kendall and spearman correlations. Psychometrika. 2000;65(1), 23-8.

19. Duque MI, Yosipovitch G, Chan YH, Smith R, Levy P. Itch, pain, and burning sensation are common symptoms in mild to moderate chronic venous insufficiency with an impact on quality of life. J Am Acad Dermatol. 2005;53(3):503-07.

20. Palfreyman SJ, Drewery-Carter K, Rigby K, Michaels JA, Tod AM. Varicose veins: A qualitative study to explore expectations and reasons for seeking treatment. J Clin Nurs. 2004;13(3):332-40.

21. Silva DK, Nahas MV Atividade física habitual e qualidade de vida relacionada à saúde em mulheres com doença vascular periférica. Rev Bras Cienc Mov. 2008;12(4):63-8.

22. Auzky O, Lanska V, Pitha J, Roztocil K. Association between symptoms of chronic venous disease in the lower extremities and cardiovascular risk factors in middle-aged women. Int Angiol. 2011;30(4):335-41.

23. Moura RM, Gonçalves GS, Navarro TP, Britto RR, Dias RC. Relationship between quality of life and the CEAP clinical classification in chronic venous disease. Braz J Phys Ther. 2010;14(2):99-05. 